\title{
PISA MATHEMATICS FRAMEWORK DALAM PENELUSURAN MATHEMATICAL LITERACY SKILLS MAHASISWA
}

\author{
Rina Oktaviyanthi ${ }^{*}$, Ria Noviana Agus, Yani Supriani \\ Universitas Serang Raya (UNSERA) \\ *rinaokta1210@yahoo.com
}

\begin{abstract}
Abstrak: Perubahan dan perkembangan jaman dewasa ini memberikan dampak pada sektor pendidikan untuk melakukan penyesuaian dan modifikasi dalam pengajaran sehingga kebutuhan peserta didik dalam hal penguasaan ilmu yang sesuai dengan karakteristik perubahan jaman dapat terpenuhi. Dewasa ini praktik-praktik pekerjaan telah mengarah pada globalisasi, reformasi daya saing, kemutakhiran teknologi informasi dan komunikasi. Untuk itu peserta didik perlu dilengkapi dengan kemampuan-kemampuan yang sesuai dengan karakteristik praktik pekerjaan masa depan tersebut.Kemampuan literasi matematik dipandang sebagai salah satu kemampuan yang dapat membantu generasi muda memenuhi tuntutan global. Langkah awal yang dapat dilakukan adalah menelusuri kemampuan literasi matematik peserta didik. Kajian ini merupakan studi pendahuluan terkait pentingnya mengetahui kemampuan literasi matematik peserta didik, khususnya pada program studi Teknik Informatika, Universitas Serang Raya sebagai landasan, arahan, dan pedoman bagi pengajar untuk mengoptimalkan potensi yang ada pada masing-masing peserta didik. Jenis penelitian ini merupakan penelitian terapan yang dilakukan dengan tujuan untuk memperoleh hasil yang berguna dari aspek kepentingan praktis yaitu berupa rumusan dasar mengenai Mathematical Literacy Skills mahasiswa Teknik Informatika. Adapun rumusan dasar yang akan dihasilkan dalam penelitian menggunakan Pisa Mathematics Framework yang meliputi kemampuan merumuskan masalah, menggunakan/ menerapkan konsep matematika, menafsirkan dan mengevaluasi hasil yang diperoleh.
\end{abstract}

Kata kunci: literasi matematik, mathematical literacy, pisa mathematics framework, teknik informatika

\section{PENDAHULUAN}

Telah menjadi pengetahuan umum bahwa beberapa dekade terakhir perkembangan jaman manusia berubah dinamis menuju lingkungan kerja abad 21. Praktek-praktek pekerjaan sudah mengadaptasi karakteristik yang mengarah pada globalisasi, reformasi daya saing, dan kemutakhiran teknologi informasi dan komunikasi. Tidak hanya pada sektor pekerjaan umum, sektor pendidikan yang merupakan pencetak generasi-generasi berpotensi pun harus melakukan penyesuaian dengan tipikal perubahan masa depan.Seperti yang diungkapkan Kift (2011), untuk menyesuaikan dengan perubahan jaman saat ini, peserta didik yang lulus harus dilengkapi dengan profil pengetahuan teknis dan non- teknis, serta keterampilan dan keahlian yang melampaui pengetahuan teknis tradisional.

"The higher education sector has been subjected to relentless change from a various aspects, and particularly by the demand that our students now graduate with a profile of knowledge, skills and attitudes that include, but go beyond, the disciplinary expertise or technical knowledge that traditionally formed the core of most university courses. These skills sets refers to 'subject-specific abilities' (of knowledge, application and problem-solving, and sources and research), 'general transferable intellectual skills' (of analysis, synthesis, critical judgment and evaluation, and autonomy and ability to 
learn), and 'key skills' (of communication and literacy, numeracy, information technology and teamwork)."

Menurut Kift (2011) keahlian-keahlian yang harus ada pada peserta didik tersebut bertujuan untuk mempersiapkan peserta didik menghadapi perubahan jaman, siap terhadap tantangan masa depan dan dapat bersinergi dengan lingkungan kerja global yang beragam.

Untuk memenuhi dan mewujudkan tujuan tersebut, standar dalam kurikulum perlu diperbaharui yang pada mulanya mengharuskan peserta didik mampu melakukan ini dan itu (students should be able to do) menjadi target pengetahuan dan kemampuan keahlian dasar yang harus dimiliki peserta didik (the basic skill competencies and knowledge expectations). Berkaitan dengan tujuan tersebut, Pacific Policy Research Center (2010) menyatakan, "To meet this challenge schools must be transformed in ways that will enable students to acquire the creative thinking, flexible problem solving, collaboration and innovative skills they will need to be successful in work and life." Dari pernyataan PPRC (2010) dapat disimpulkan bahwa kemampuan yang perlu diterapkan pada peserta didik adalah pemikiran kreatif, pemecahan masalah yang fleksibel, kolaborasi dan keterampilan inovatif. Memokuskan pada kemampuan pemecahan masalah, Schneider (dalam PPRC, 2010) menyatakan bahwa peserta didik perlu dilatihkan kemampuan literasi matematika (mathematical literacy skills) yang memiliki definisi, "The capability for a contextual and detailed understanding of a mathematical problem in order to enable analysis, synthesis, evaluation, and ultimately decision-making", untuk membantu memunculkan potensi pemecahan masalah dan mengasah kemampuan tersebut secara optimal.

Kemampuan literasi matematika dipandang sebagai salah satu kemampuan yang dapat membantu generasi muda memenuhi tuntutan global. American Association of Colleges of Teacher Education (2010) mengungkapkan dalam $21^{\text {st }}$ Century Knowledge And Skills in Educator Preparation bahwa, "The mastery of 21st century skills such as critical thinking, problem-solving, communication, collaboration and creativity and innovation need mathematical literacy skills. Today more than ever, individuals must be able to perform non-routine, creative tasks if they are to succeed." Kemampuan literasi matematika tersebut adalah persyaratan untuk berpikir kritis, memecahkan masalah, mengomunikasikan ide dan masalah, menemukan informasi yang baik dan cepat dan menggunakan informasi yang diperoleh secara efektif. Kemampuan ini bukan hanya untuk sukses pada karir tetapi untuk bertahan hidup dan kualitas pribadi. Pentingnya menanamkan sejak dini kemampuan mathematical literacy terbuka pada semua bidang, aspek dan jurusan, tidak terkecuali jurusan teknik. Berkenaan dengan kepentingan tersebut, American Society for Engineering Education (2013) menyatakan bahwa,

"Problem solving as a core engineering skills need a mathematical literacy skills and should be cultivated through multiple iterations of design throughout the curriculum. Design consists of several small problems; academia should provide more open-ended questions and show that there isn't always a "right" answer, thus encouraging creativity and flexible thinking and allowing students to identify the problem and figure out possible avenues to solve it. A common fault is to try to solve a problem without fully understanding it."

Secara formal, definisi literasi matematika dalam kerangka PISA (Programme Internationale for Student 
Assessment) Matematika 2012 disampaikan oleh OECD (2013) dan Stacey (2010) sebagai berikut:

"Mathematical literacy is an individual's capacity to formulate, employ, and interpret mathematics in a variety of contexts. It includes reasoning mathematically and using mathematical concepts, procedures, facts and tools to describe, explain and predict phenomena. It assists individuals to recognize the role that mathematics plays in the world and to make the wellfounded judgments and decisions needed by constructive, engaged and reflective citizens."

Dari definisi di atas, terdapat tiga hal utama yang menjadi pokok pikiran dari konsep mathematical literacy, yaitu (1) kemampuan merumuskan, menerapkan, dan menafsirkan matematika dalam berbagai konteks yang selanjutnya disebut sebagai proses matematika; (2) pelibatan penalaran matematis dan penggunaan konsep, prosedur, fakta, dan alat matematika untuk mendeskripsikan, menjelaskan, dan memprediksi fenomena; dan (3) manfaat dari kemampuan literasi matematika yaitu dapat membantu seseorang menerapkan matematika ke dalam dunia sehari-hari sebagai wujud dari keterlibatan masyarakat yang konstruktif dan reflektif.

Adapun manfaat menggali mathematical literacy skills peserta didik diantaranya yaitu sebagai media peserta didik untuk (1) lebih terlibat dalam pembelajaran dengan penyediaan masalah kehidupan nyata dalam konteks berbeda, (2) memperluas wawasan, pengetahuan dan keterampilan dasar matematika peserta didik, (3) membangun kemampuan memahami terminologi matematika, informasi numerik dan spasial yang dikomunikasikan dalam tabel, grafik, diagram dan teks, (4) mengembangkan penggunaan keterampilan dasar matematika dalam menganalisis situasi kritis dan menghasilkan pemecahan masalah yang kreatif (Gintis, H., 2010).

\section{KAJIAN PUSTAKA}

A. PISA (Programme Internationale for Student Assessment)

PISA adalah penilaian standar internasional yang dikembangkan bersama oleh negara-negara peserta meliputi domain matematika, membaca dan ilmu pengetahuan. Domain tersebut tidak hanya dalam hal apakah peserta didik dapat mereproduksi pengetahuan mata pelajaran tertentu, tetapi juga apakah mereka dapat memperkirakan dan menerapkan pengetahuan dalam situasi baru. Domain lainnya yaitu problem solving dan financial literacy (Mullen, J., 2009). PISA dalam studinya menggunakan istilah 'literasi' untuk merujuk pada penilaian bukan hanya pada pengetahuan sebagai domain tetapi juga kemampuan mengaplikasikan pengetahuan tersebut (Sawyer, A., 2005). Penekanan penilaian PISA yaitu pada penguasaan proses, pemahaman konsep dan kemampuan untu berfungsi dalam berbagai situasi dalam setiap domain. Penilaian PISA mengambil pendekatan yang luas untuk mengukur pengetahuan, keterampilan dan sikap yang mencerminkan perubahan pada prioritas sekolah dan tugas serta kemungkinan tantangan di luar sekolah. Hal tersebut didasarkan pada model dinamis pembelajaran seumur hidup dimana pengetahuan dan keterampilan diperlukan untuk proses beradaptasi selama hidup berlangsung. PISA berfokus pada kompetensi yang dibutuhkan peserta didik di masa mendatang dan berusaha menilai kemampuan peserta didik dalam mencari penyelesaian masalah melalui proses menghubungkan masalah yang dihadapi dengan pengetahuan yang sudah dipelajari dan mengevaluasi pilihan keputusan yang peserta didik ambil untuk menyelesaikan masalah.

Adapun alasan PISA berorientasi mengambil pendekatan yang luas seperti yang 
dijelaskan oleh OECD (2010) adalah sebagai berikut:

a. In reading, the capacity to develop interpretations of written material and to reflect on the content and qualities of text are central skills. In mathematics, the ability to answer familiar textbook questions must be supplemented by being able to reason quantitatively, to represent relationships or dependencies, and to connect the context and structure of a problem with mathematics when it comes to deploying mathematical skills in real world problems. In science, having specific knowledge, such as the names of plants and animals, is of less value than understanding broad topics such as energy consumption, biodiversity and human health in thinking about the issues under debate in the adult community.

$b$. In an international setting, a focus on curriculum content would restrict attention to curriculum elements common to all or most countries. This would force many compromises and result in an assessment too narrow to be of value for governments wishing to learn about the strengths and innovations in the education systems of other countries.

c. Certain broad, general skills are essential for students to develop. They include communication, adaptability, flexibility, problem solving and the use of information technologies. These skills are developed across the curriculum and an assessment of them requires a broad cross-curricular focus.

Penilaian PISA menyediakan tiga hasil utama, yaitu (1) dasar indikator yang memberikan gambaran profil dasar pengetahuan dan keterampilan peserta didik, (2) indikator berasal dari kuisioner kontekstual yang menunjukkan bagaimana hubungan keterampilan peserta didik dengan demografis penting seperti sosial dan ekonomi, dan (3) tren indikator yang muncul dari sifat pengumpulan data yang menunjukkan perubahan berkala baik dalam level hubungan antar peserta didik maupun level variabel latar belakang sekolah (Ojose, B., 2011).

\section{B. Mathematical Literacy Skills}

Mathematical literacy atau keaksaraan matematika bukan diartikan sebagai pengetahuan terperinci dari Kalkulus, Persamaan Differensial, Topologi, Aljabar Linier, Aljabar Abstrak atau formula canggih dan kompleks. Melainkan pemahaman yang lebih luas dan apresiasi terhadap pencapaian kemampuan matematika. Secara sederhana mathematical literacy adalah pengetahuan untuk mengetahui dan menerapkan matematika dasar dalam kehidupan manusia sehari-hari. Ojose (2011) mendefinisikan mathematical literacy sebagai kapasitas individu dalam mengidentifikasi dan memahami aturan dasar matematika yang berperan di dunia, membuat penilaian dan melibatkan matematika dalam setiap kegiatan individu. Secara formal definisi mathematical literacy dalam kerangka PISA disampaikan oleh Organization for Economic Corporation and Development (OECD) yaitu, "Mathematical literacy is an individual's capacity to formulate, employ, and interpret mathematics in a variety of contexts. It includes reasoning mathematically and using mathematical concepts, procedures, facts and tools to describe, explain and predict phenomena. It assists individuals to recognize the role that mathematics plays in the world and to make the well-founded judgments and decisions needed by constructive, engaged and reflective citizens (OECD, 2013)." 
Literasi matematis memokuskan pada kemampuan siswa dalam menganalisis, bernalar, dan mengomunikasikan ide secara efektif melalui proses merumuskan, memecahkan dan menafsirkan solusi dari masalah matematika dalam berbagai situasi. Penilaian matematika PISA yang sejauh ini dirancang berkaitan dengan:

a. Proses, yaitu merumuskan situasi secara matematis; menggunakan konsep matematika, fakta, prosedur dan penalaran; menafsirkan; menerapkan; dan mengevaluasi hasil. Proses tersebut measing-masing mengacu pada tujuh dasar kemampuan matematika, yatiu komunikasi, mematematisasikan masalah, representasi, penalaran dan argumentasi, strategi untuk merancang pemecahan masalah, menggunakan simbol baik secara formal maupun teknik bahasa operasi, serta menggunakan alat matematika yang rinci pada pemecahan masalah.

b. Isi, didefinisikan terutama dalam hal empat ide yang menyeluruh (kuantitas, ruang dan bentuk, perubahan dan hubungan, dan ketidakpastian data) yang berhubungan dengan kurikulum standar seperti bilangan, aljabar, dan geometri.

c. Konteks, didefinisikan dalam aspek dunia individu dimana masalah dapat muncul dan berkembang. Hal ini mengidentifikasikan empat kategori yaitu personal, pendidikan, sosial dan sains. (OECD, 2013)

Pengertian mathematical literacy yang disampaikan PISA merujuk pada kemampuan pemodelan matematika, yang pada kerangkakerangka PISA sebelumnya juga digunakan sebagai batu pijakan dalam mendefinisikan konsep literasi. Menurut OECD (2013), seorang pemecah masalah matematika yang aktif adalah seseorang yang mampu menggunakan matematikanya dalam memecahkan masalah kontekstual melalui beberapa tahapan seperti yang diuraikan PISA dalam model literasi matematika pada gambar di bawah ini.

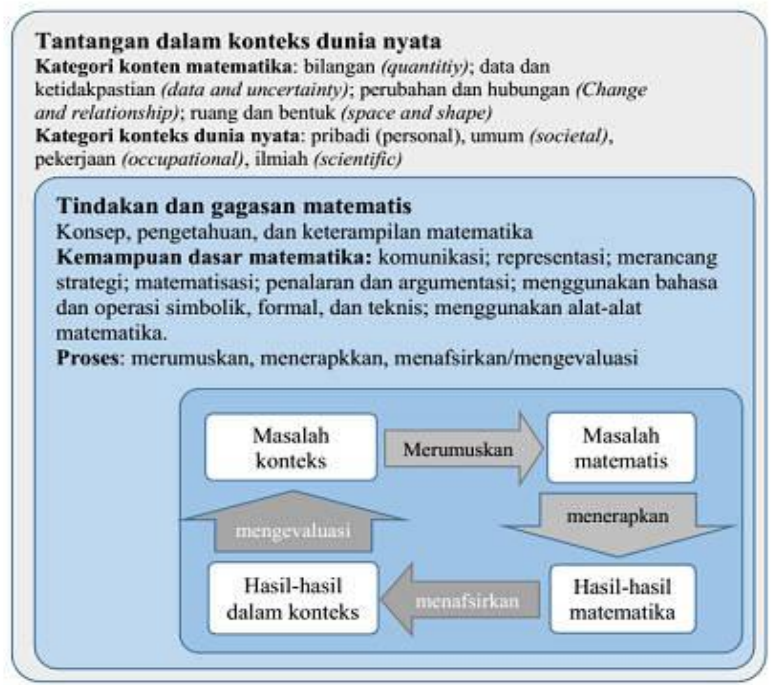

Gambar 1. Model Literasi Matematis dalam Praktik (OECD, 2003; Stacey $^{17}$, 2012)

Penjelasan model literasi matematika pada gambar di atas dijelaskan sebagai berikut:

1) Literasi matematika berangkat dari suatu masalah yang berasal dari dunia nyata. Masalah ini kemudian dikategorikan ke dalam dua cara, yaitu (1) kategori konteks, dan (2) kategori dunia nyata.

2) Untuk memecahkan masalah kontekstual, seseorang harus menerapkan tindakan dan gagasan matematis untuk menyelesaikan masalah ini. Tindakan ini melibatkan kemampuan mengggunakan pengetahuan dan keterampilan matematika, hal ini sangat bergantung pada kemampuan yang disebut PISA sebagai kemampuan dasar matematika (Fundamental Mathematical Capabilities).

3) Proses literasi matematis berangkat dari mengidentifikasi masalah kontektual, lalu merumuskan masalah tersebut secara matematis berdasarkan konsep-konsep dan hubungan-hubungan yang melekat pada masalah. Setelah mengubah masalah kontekstual tersebut ke dalam bentuk matematika, langkah selanjutnya adalah menerapkan prosedur matematika untuk memperoleh 'hasil matematika'. Tahapan ini biasanya melibatkan aktivitas seperti memanipulasi, bernalar, dan menghitung. Hasil matematika yang diperoleh kemudian ditafsirkan kembali dalam bentuk hasil yang berhubungan dengan masalah awal. 
4) Dalam proses merumuskan, menerapkan, dan menafsirkan, kemampuan dasar matematis (KDM) akan diaktifkan secara berturut-turut dan bersamaan bergantung pada konten matematika dari topik-topik yang sesuai untuk memperoleh solusi. Bagaimanapun, ketiga proses ini kadang tidak dilibatkan semua dalam memecahkan masalah. Sebagai contoh, pada beberapa kasus, bentuk-bentuk representasi matematis seperti grafik dan persamaan dapat ditafsirkan secara langsung untuk memperoleh suatu solusi. Untuk alasan inilah, banyak dari soal-soal PISA yang hanya melibatkan beberapa tahap dari siklus pemodelan PISA. Selain itu, tidak menutup kemungkinan bahwa seorang pemecah masalah akan melakukan tindakan berulang-ulang pada setiap proses yang dilakukan, seperti kembali mempertimbangkan keputusan atau asumsi awal yang diambil sebelum kembali lagi untuk melanjutkan proses selanjutnya.

\section{PISA Mathematical Framework}

PISA Mathematical Framework menjelaskan teoritis dari penilaian matematika PISA, termasuk definisi formal literasi matematika, proses matematika yang dilakukan peserta didik saat menggunakan literasi matematika, dan kemampuan matematika dasar yang mendasari prosesproses tersebut. Kerangka tersebut terorganisir menjadi empat bagian utama, yaitu (a) definition of mathematical literacy, menjelaskan dasar-dasar teoritis penilaian matematika PISA termasuk definisi formal literasi matematika; (b) organizing the domain, menjelaskan tiga aspek yaitu (i) proses matematika dan kemampuan matematika dasar, (ii) konten pengetahuan matematika yang relevan, (iii) konteks masalah sebagai tantangan matematika; dan (c) assessing mathematical literacy, menguraikan masalah struktural tentang penilaian.

\section{Defining mathematical literacy}

Pemahaman matematika adalah pusat kesiapan peserta didik untuk menghadapi masyarakat modern. Permasalahan yang muncul dan situasi yang dihadapi dalam kehidupan sehari-hari termasuk didalamnya konteks profesional, memerlukan beberapa tingkat pemahaman, penalaran, dan alat matematika. Matematika merupakan salah satu alat utama untuk menghadapi masalah, untuk itu sangat penting bagi peserta didik memiliki pemahaman tentang penerapan matematika mulai dari memahami masalah dan memecahkan masalah secara matematik. Literasi matematik bukan merupakan atribut yang harus ada atau tidak ada pada seorang individu. Sebaliknya, literasi matematik adalah kemampuan dasar yang dimiliki individu dan berpotensi untuk berkembang. Definisi mathematical literacy menurut PISA 2012 yaitu proses individu dalam melakukan rumusan, mempekerjakan dan menafsirkan matematika ke dalam beragam konteks. Hal ini mencakup penalaran secara matematis, menggunakan konsep dan prosedur matematika, menjelaskan dan memprediksi fenomena. Proses ini membantu individu dalam memahami peran yang dimainkan matematika dalam aspek kehidupan dunia.

\section{Organising the domain}

PISA Mathematical Framework mendefinisikan domain matematika untuk menggambarkan pendekatan penilaian literasi matematika pada peserta didik. Untuk tujuan penilaian, Stacey (2012) mengungkapkan bahwa definisi literasi matematik dapat dianalisis ke dalam tiga aspek yang saling terkait, yaitu

(a) the mathematical processes that describe what individuals do to connect the context of the problem with mathematics and thus solve the problem, and the capabilities that underlie those processes;

(b) the mathematical content that is targeted for use in the assessment items; and

(c) the contexts in which the assessment items are located.

Hubungan antara proses matematik dan kemampuan dasar matematik dapat dilihat pada tabel 1 . 
Tabel 1. Hubungan Antara Proses Matematik dan Kemampuan Dasar Matematik

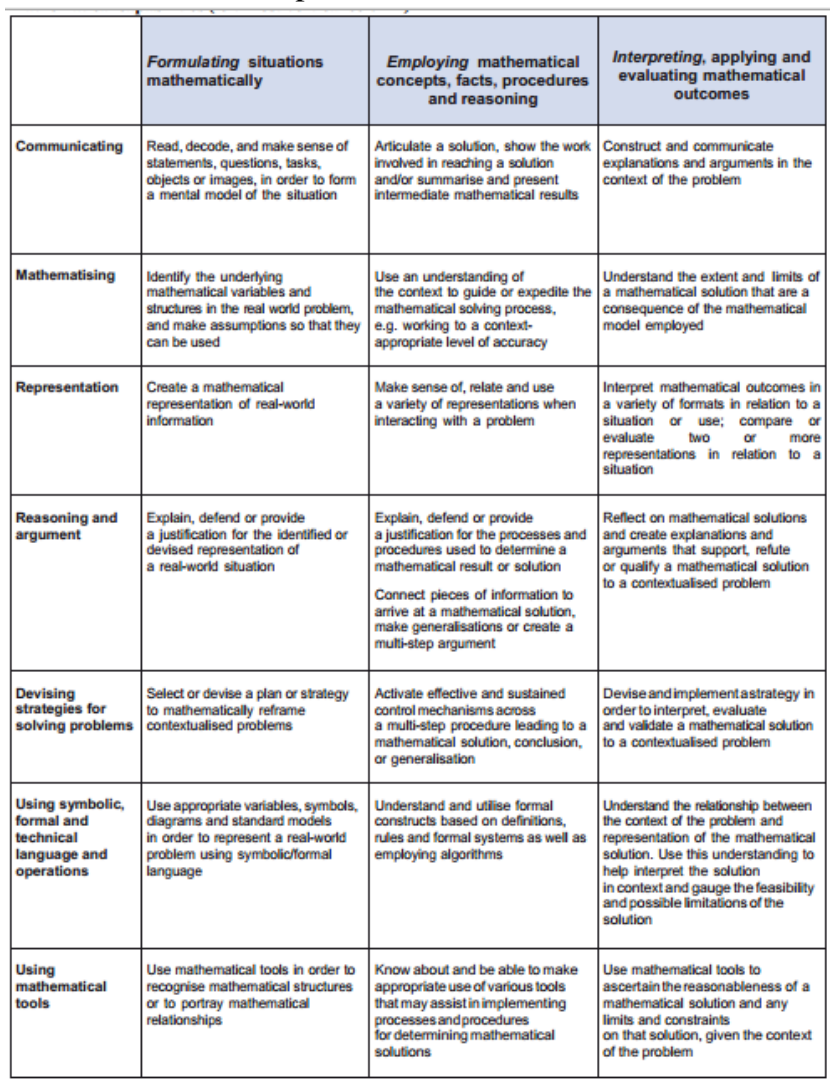

Assessing mathematical literacy

Struktur penilaian literasi matematik dapat dilihat pada tabel-tabel berikut.

Tabel 2. Distribusi Perkiraan Skor Poin dalam

Matematika, Berdasarkan Kategori Proses

\begin{tabular}{|l|c|}
\hline \multicolumn{1}{|c|}{ Process category } & Percentage of score points \\
\hline Formulating situations mathematically & Approximately 25 \\
\hline Employing mathematical concepts, facts, procedures and & Approximately 50 \\
\hline Interpreting, applying and evaluating mathematical outcomes & Approximately 25 \\
\hline TOTAL & 100 \\
\hline
\end{tabular}

Tabel 3. Distribusi Perkiraan Skor Poin dalam Matematika, Berdasarkan Kategori Konten (isi)

\begin{tabular}{|l|c|}
\hline \multicolumn{1}{|c|}{ Content category } & Percentage of score points \\
\hline Change and relationships & Approximately 25 \\
\hline Space and shape & Approximately 25 \\
\hline Quantity & Approximately 25 \\
\hline Uncertainty and data & Approximately 25 \\
\hline TOTAL & 100 \\
\hline
\end{tabular}

Tabel 4. Distribusi Perkiraan Skor Poin dalam

Matematika, Berdasarkan Kategori Konteks

\begin{tabular}{|l|c|}
\hline \multicolumn{1}{|c|}{ Context category } & Percentage of score points \\
\hline Personal & Approximately 25 \\
\hline Occupational & Approximately 25 \\
\hline Societal & Approximately 25 \\
\hline Scientific & Approximately 25 \\
\hline TOTAL & 100 \\
\hline
\end{tabular}

Tabel 5. Deskripsi Skala Kemampuan Matematik (skills) (2003-2009)

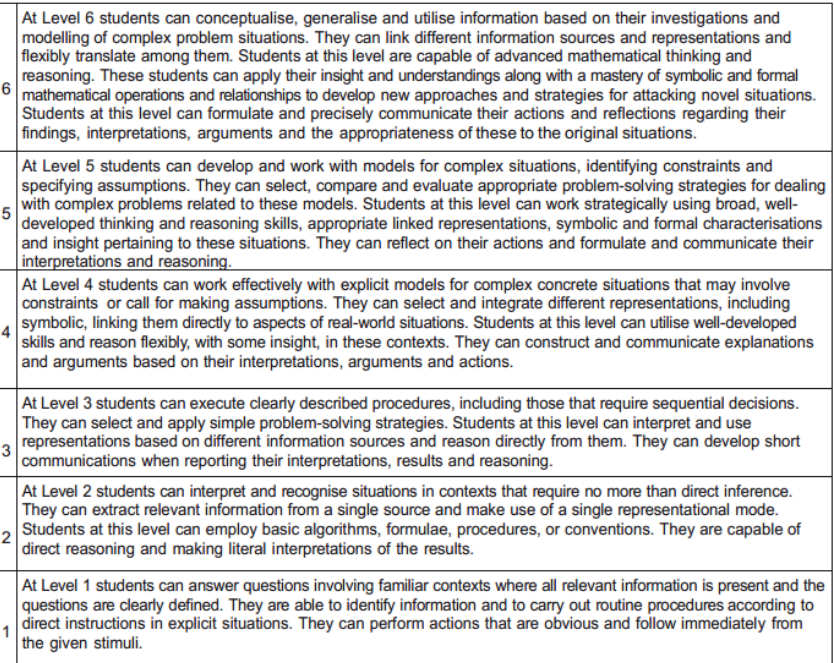

\section{METODE}

Tujuan penelitian ini adalah menelusuri dan mendeskripsikan Mathematical Literacy Skills Mahasiswa Teknik Informatika menggunakan Pisa Mathematics Framework. Hal tersebut diperoleh dengan mengungkap gambaran kemampuan Mathematical Literacy berdasarkan kemampuan dasar subjek dan gambaran respon yang diajukan peneliti pada subjek baik melalui pertanyaanpertanyaan matematika dan non matematika selama pengambilan data berlangsung. Peneliti melakukan pengamatan secara cermat dan mendalam yaitu dengan eksplorasi informasi terhadap subjek penelitian mengenai apa yang dipikirkan, dikerjakan, ditulis, dan diucapkan subjek yang berhubungan dengan daya matematis ditinjau dari kepribadiannya. Eksplorasi informasi itu dilakukan melalui kegiatan wawancara berbasis tugas. 
Hasil eksplorasi informasi yang telah dilakukan menghasilkan data yang kemudian dideskripsikan dan dianalisis secara murni melalui ungkapan-ungkapan yang disampaikan berupa kata-kata untuk memperoleh gambaran alami Mathematical Literacy Skills Mahasiswa Teknik Informatika menggunakan Pisa Mathematics Framework. Hasil data tersebut merupakan gambaran apa adanya tentang hubungan keterpaduan, fungsional maupun konsekuensial antara variabel terkait.

Dalam melakukan pengamatan dan pemeriksaan terhadap subjek penelitian, peneliti bertindak sebagai instrumen utama yang tidak dapat digantikan dan diwakilkan oleh sesuatu yang lain. Peneliti juga tidak melakukan manipulasi atau tindakan apapun sehingga data yang diperoleh tetap orisinil. Peneliti lebih mementingkan hal-hal yang dipikirkan dan dilakukan subjek selama proses pengambilan data berlangsung daripada hasil akhir jawaban subjek dari masalah yang diberikan peneliti. Dengan demikian, penelitian ini menggunakan pendekatan kualitatif.

Berdasarkan cara mengungkap data untuk memperoleh deskripsi penelusuran Mathematical Literacy Skills Mahasiswa Teknik Informatika menggunakan Pisa Mathematics Framework, yaitu dengan mengeksplorasi dan menggali informasi terhadap apa yang dipikirkan dan dilakukan subjek, maka penelitian ini termasuk kategori penelitian eksploratifdeskriptif. Dengan demikian penelitian ini merupakan penelitian deskriptif eksploratif dengan pendekatan kualitatif.

Subjek populasi penelitian adalah seluruh mahasiswa Teknik Informatika tingkat satu pada Fakultas Teknologi Informasi yang diambil dengan teknik random (acak) sederhana dari setiap kelas.

\section{KESIMPULAN}

Kajian awal ini diharapkan dapat memberikan gambaran manfaat, membawa kebaikan, dan mendatangkan kontribusi pada pelaksanaan penelitian lanjutan diantaranya, yaitu:

1. Memperoleh sebaran dan rumusan dasar mengenai Mathematical Literacy Skills mahasiswa Teknik Informatika yang dapat dijadikan sebagai pengetahuan dasar pengajar dalam menentukan penilaian.

2. Rumusan dasar mengenai kemampuan Mathematical Literacy ini dapat digunakan pengajar untuk pertimbangan dalam mengembangkan metode pembelajaran dan instrument penilaian hasil belajar.

3. Hasil penelitian ini dapat disusun menjadi suatu peta kompetensi sehingga pengajar memiliki informasi yang cukup untuk mengembangkan aspek dari kemampuan Mathematical Literacy mahasiswa yang masih rendah.

\section{DAFTAR PUSTAKA}

American Association of Colleges of Teacher Education (AACTE).(2010).21 $1^{\text {st }}$ Century Knowledge and Skills in Educator Preparation. Amerika: Pearson.

American Society for Engineering Education (ASEE).(2013). Transforming Undergraduate Education in Engineering. Arlington: ASEE.

Gintis, H. (2010). Mathematical Literacy for Humanists. USA: Library of Congress Cataloging.

Kitf, S. (2011). 21 $1^{\text {st }}$ Century Climate for Change: Curriculum Design for Quality 
Learning Engagement in Law. Legal Education Review, Volume 19, pp. 1-30.

Mullen, J. (2009). Enhancing Mathematical Literacy. Mathematical and Computing Sciences asters, Paper 90.

Ojose, B. (2011). Mathematics Literacy: Are We Able To Put The Mathematics We Learn Into Everyday Use?, Journal of Mathematics Education, Volume 4, Number 1, pp. 89-100.

Organization for Economic Corporation and Development (OECD). (2010). PISA 2012 mathematics Framework. Finlandia: OECD Publishing.

Organization for Economic Corporation and Development (OECD). (2013). PISA 2012 Assessment and Analytical Framework: Mathematics, Reading, Science, Problem Solving and Financial Literacy. Finlandia: OECD Publishing.

Pacific Policy Research Center (PPRC). (2010). $21^{\text {st }}$ Century Skills for Students and Teachers. Honolulu: Kamehameha Schools, Research and Evaluation Division.

Sawyer, A. (2005) Education for Early Mathematical Literacy: More Than Maths Know-How. Australia: Queensland University of Technology.

Stacey, K. (2010). Mathematical and Scientific Literacy Around The World.Journal of Science and Mathematics Education in Southeast Asia, Volume 33, Number 1, pp. 1-16.

Stacey, K. (2012). The International Assessment of Mathematical Literacy. $12^{\text {th }}$ International Congress on Mathematical
Education 8-15 July 2012, COEX, Seoul, Korea. 